\title{
ANALISIS KANDUNGAN SERAT DAN UJI HEDONIK PADA PRODUK SNACK BAR TEPUNG BERAS MERAH (Oryza Nivara L) DAN KACANG HIJAU (Phaseolus Radiatus $L$ )
}

\author{
Nanda Nathasya YP1*, Restu Amalia H ${ }^{2}$, Ardhika Ulfah ${ }^{3}$ \\ ${ }^{1}$ Sekolah Tinggi Ilmu Kesehatan Holistik \\ *Korespondensi: Kp. Cimanglid RT. 06 RW. 02 Ds. Sukatani, Kec. Sukatan, Kab. Purwakarta- Jawa Barat. \\ 41167. Email: nandanathasyayunic21@gmail.com
}

\begin{abstract}
ABSTRAK
Latar Belakang: Tingkat konsumsi serat masyarakat Indonesia masih rendah. Snack bar merupakan makanan selingan yang terbuat dari serealia dan kacang-kacangan dapat menjadi alternatif makanan sumber serat.

Tujuan Penelitian: Mengetahui pengaruh rasio tepung beras merah dan kacang hijau terhadap uji hedonik, kandungan serat, dan formulasi terbaik pada pembuatan snack bar serta mengetahui persentase serat yang terkandung dalam snack bar tersebut dibandingkan dengan angka kecukupan gizi (AKG) serat.

Metode: Penelitian ini adalah penelitian kuantitatif menggunakan Rancangan Acak Lengkap (RAL) dengan perbandingan jumlah rasio tepung beras merah dan kacang hijau dalam pembuatan snack bar dengan tiga kali pengulangan. Penelitian ini terdiri dari tiga tahap yaitu pembuatan snack bar, analisis kandungan serat dan uji hedonik. Uji hedonik menggunakan 60 orang panelis tidak terlatih. Analisis statistik dilakukan menggunakan One Way Anova dan kruskal wallis.

Hasil: kandungan serat snack bar dari tiga formula berbeda tidak berbeda signifikan $(p>0.05)$ dengan nilai $p$ value 0.055 . hasil uji hedonik terhadap parameter warna diperoleh $p$ value 0.699 , aroma dengan $p$ value 0.913 , rasa diperoleh $p$ value 0.762 dan tekstur dengan $p$ value 0.708 atau $(p<0,05)$.

Simpulan: Perbedaan rasio tepung beras dan kacang hijau tidak berpengaruh terhadap kandungan serat dan uji hedonik pada snack bar.
\end{abstract}

Kata kunci: serat, snack bar, tepung beras merah, kacang hijau.

\begin{abstract}
Background: The level of fiber consumption of Indonesian people is known to be low. Snack bars are snacks made from cereals and nuts that can be an alternative source of fiber.

Research Objectives: To determine the effect of the ratio of brown rice flour and green beans to the hedonic test, fiber content, and the best formulation in making snack bars, and to determine the percentage of fiber contained in the snack bar compared to the nutritional adequacy rate $(R D A)$.

Methods: This study was a quantitative study using a completely randomized design with a ratio of brown rice flour and green beans in making snack bars. This study consisted of three stages, making snack bars, analyzing fiber content and hedonic test. The hedonic test was followed by 60 untrained panelists. Statistical analysis was performed using One Way Anova and kruskal wallis.

Results: the snack bar fiber content of the three different formulas was not significantly different $(p>0.05)$ with $p$-value 0.055. The hedonic test results on color parameters obtained $p$-value 0.699, aroma with $p$-value 0.913, taste obtained $p$-value 0.762 and texture with $p$ value 0.708.
\end{abstract}

Conclusion: The difference in the ratio of rice flour and green beans has no effect on fiber content and hedonic test on the snack bar. 
Key words: fiber, snack bar, brown rice flour, green beans.

\section{PENDAHULUAN}

Perkembangan teknologi menyebabkan perubahan pada bidang pangan dan gizi. Salah satu dampak dari globalisasi di bidang pangan dan gizi adalah terjadinya pergeseran pola konsumsi dengan gizi yang tidak seimbang. Jenis makanan yang tidak seimbang tersebut bersifat praktis, seperti aneka makanan siap saji (junk food) yang biasanya mengandung tinggi kalori, tinggi lemak dan natrium, sementara kandungan serat, vitamin dan mineral jarang sekali di jumpai pada makanan-makanan tersebut [1]. Konsumsi lemak dan karbohidrat yang berlebih dan rendahnya asupan serat atau tidak sesuai dengan kebutuhan tubuh dapat menyebabkan masalah kesehatan hingga kematian [2].

$\mathrm{Di}$ Indonesia serat banyak didapatkan dari konsumsi serealia, sayuran dan buah. Perubahan pola konsumsi pangan di Indonesia menyebabkan berkurangnya konsumsi sayuran dan buah-buahan [3]. Tingkat konsumsi serat masyarakat Indonesia dilihat dari tingkat konsumsi sayur dan buah sebagai sumber serat yang masih rendah atau tidak memenuhi angka kecukupan gizi (AKG) perorang perhari. Berdasarkan hasil survei nasional 2001 rata-rata penduduk Indonesia mengoonsumsi serat 10,5 g/hari, masih kurang dari setengah anjuran serat harian, yaitu $30 \mathrm{~g} /$ hari [4][5], sehingga dibutuhkan upaya untuk menigkatkan asupan serat dengan alternatif pengembangan produk selingan sumber serat yang dapat diformulasikan dalam bentuk snack bar.

Bentuk bar dipilih karena kemudahan dalam konsumsi (praktis). Pangan berbentuk bar mudah dibuat dan di kreasikan dengan berbagai macam bahan pangan lainnya [6]. Snack bar merupakan makanan selingan berbentuk batang dan merupakan campuran dari berbagai bahan kering seperti sereal, kacang-kacangan, buah-buahan kering yang digabungkan menjadi satu dengan bantuan binder [7].

Tujuan penelitian ini adalah mendapatkan produk olahan pangan sumber serat pada produk snack bar dengan penambahan tepung beras merah dan kacang hijau.

\section{METODE PENELITIAN}

Penelitian terdiri dari beberapa tahapan, yaitu pembuatan kacang hijau kering, pembuatan snackbar, analisis kandungan serat dan uji hedonik. Rancangan penelitian pada penelitian ini adalah Rancangan Acak Lengkap (RAL) dengan satu faktor yaitu perbandingan jumlah rasio tepung beras merah dan kacang hijau.

\begin{tabular}{cc}
\hline Formula & $\begin{array}{c}\text { Perbandingan Tepung beras } \\
\text { merah : Kacang hijau }\end{array}$ \\
\hline F1 & $40: 60$ \\
F2 & $50: 50$ \\
F3 & $60: 40$ \\
\hline
\end{tabular}

Tahapan pertama, pembuatan kacang hijau kering menggunakan oven dengan suhu $100^{\circ} \mathrm{C}$ selama 15 menit, kemudian dilanjutkan dengan pembuatan snack bar. pencampuran bahan baku tepung beras merah dan kacang hijau sesuai dengan formulasi ( $\mathrm{F} 1=40 ; 60 \mathrm{~g}, \mathrm{~F} 2=50 ; 50 \mathrm{~g}, \mathrm{~F} 3=$ 60;40 g) serta bahan tambahan lainya seperti gula, madu, garam, telur, coklat blok, susu full cream, dan margarin. Adonan dimasukkan ke dalam loyang dan dipanggang menggunakan oven $120^{\circ} \mathrm{C}$ selama 45 menit. Setelah dilakukan pemanggangan dilakukan pendinginan selama 30 menit.

Tahap kedua adalah melakukan analisis laboratorium kandungan serat. Kandungan serat pada snack bar tepung beras merah dan kacang hijau dengan metode gravimetri dengan tiga kali pengulangan analisis.

Uji hedonik untuk menilai tingkat kesukaan produk dilakukan pada panelis tidak terlatih sebanyak 60 orang terhadap parameter uji hedonik meliputi warna, aroma, rasa, dan tekstur di nilai dengan skala hedonik. Skala nilai yang dapat diberikan panelis untuk menilai produk nugget yaitu 1 (sangat tidak suka), 2 (tidak suka), 4 (suka) dan 5 (sangat suka). 
Penilaian uji hedonik bersifat spontan, dimana panelis diminta untuk menilai produk secara langsung saat itu juga tanpa membandingkannya dengan produk sebelum atau sesudahnya.

Tahap ketiga yaitu Penentuan formula terpilih produk snack bar dilakukan dengan menggunakan metode perbandingan antara hasil uji hedonik dan kandungan serat produk. Persentase tingkat kepentingan dari parameter uji hedonik dan kandungan serat yaitu, uji hedonik 40\% dan kandungan serat $60 \%$. Kandungan serat snack bar dari formula yang terpilih kemudian dibandingkan dengan angka kecukupan serat pada AKG.

Perbedaan kandungan serat dan hasil uji hedonik kemudian dianalisis lebih lanjut menggunakan software statistik menggunakan One Way Anova dan kruskal wallis.

\section{HASIL PENELITIAN}

Tabel 1.1 Kadar Serat Snack Bar pada Berbagai Formulasi

Tepung Beras Merah dan Kacan Hijau

\begin{tabular}{ccc}
\hline \multicolumn{3}{c}{ Rerata \pm SD (n=9) } \\
\hline Formula & Kadar Serat $(\%)$ & Nilai $\boldsymbol{p}$ \\
\hline F1 & $0.96 \pm 0.09$ & \\
F2 & $1.04 \pm 0.04$ & $0.055^{*}$ \\
F3 & $1.08 \pm 0.06$ & \\
\hline \multicolumn{2}{c}{ Keterangan: ${ }^{*} p$ value $<0,05$ terdapat perbedaan signifikan }
\end{tabular}

Berdasarkan Tabel 1.1 hasil analisis kandungan serat snack bar tepung beras merah dan kacang hijau menggunakan uji One Way Anova menunjukkan bahwa snack bar tepung beras merah dan kacang hijau Formula 1, 2, dan 3 tidak terdapat perbedaan signifikan ( $p>0.05)$, artinya tidak ada pengaruh antara ratio tepung beras dan kacang hijau terhadap kandungan serat snack bar tepung beras merah dan kacang hijau.

Uji hedonik untuk menilai tingkat kesukaan produk dilakukan pada panelis tidak terlatih sebanyak 60 orang terhadap parameter uji hedonik meliputi warna, aroma, rasa, dan tekstur dari snack bar tepung beras merah dan kacang hijau yang di nilai dengan skala hedonik.
Uji hedonik snack bar tepung beras merah dan kacang hijau menggunakan kruskal wallis test diperoleh $p$ value $0.699 \quad(\mathrm{P}>0.05)$. Pada parameter aroma $p$ value $0.913 \quad(\mathrm{P}>0.05)$, parameter rasa $p$ value $0.762(\mathrm{P}>0.05)$ dan parameter tekstur $p$ value $0.708 \quad(\mathrm{P}>0.05)$, sehingga dapat disimpulkan bahwa tidak ada pengaruh antara rasio tepung beras dan kacang hijau terhadap uji hedonik snack bar dari parameter warna, aroma, rasa, dan tekstur tiap formulasi. Adapun hasil dari penentuan formula terpilih yang dilakukan dilakukan berdasarkan hasil analisis kandungan serat dan uji hedonik snack bar. Penentuan formula terpilih ini didapat dengan hasil ranking. Adapun formula terpilih dapat dilihat pada Tabel 1.3.

Tabel 1.2 Tingkat kesukaan snack bar pada beberapa formulasi

tepung beras merah dan kacang hijau

\begin{tabular}{ccccl}
\hline \multicolumn{5}{c}{ Rerata \pm SD } \\
\hline Parameter & F1 & F2 & F3 & Nilai $\boldsymbol{p}$ \\
\hline Warna & $3.38 \pm 0.49$ & $3.40 \pm 0.49$ & $3.45 \pm 0.53$ & 0.699 \\
Aroma & $3.47 \pm 0.50$ & $3.42 \pm 0.56$ & $3.43 \pm 0.50$ & 0.913 \\
Rasa & $3.42 \pm 0.53$ & $3.42 \pm 0.53$ & $3.48 \pm 504$ & 0.762 \\
Tekstur & $3.47 \pm 0.56$ & $3.53 \pm 0.54$ & $3.55 \pm 0.53$ & 0.708 \\
\hline
\end{tabular}


Tabel 1.3 Tabel Skoring Penentuan Formula Terpilih

\begin{tabular}{ccccc}
\hline Formula & $\begin{array}{c}\text { Uji kesukaan } \\
\mathbf{( 4 0 \% )}\end{array}$ & $\begin{array}{c}\text { Kadar serat } \\
\mathbf{( 6 0 \% )}\end{array}$ & $\begin{array}{c}\text { Skor } \\
\mathbf{( 1 0 0 \% )}\end{array}$ & $\begin{array}{c}\text { Hasil } \\
\text { ranking }\end{array}$ \\
\hline F1 & 1,372 & 0,576 & 1,948 & 3 \\
F2 & 1,374 & 0,624 & 1,998 & 2 \\
F3* & 1,39 & 0,648 & 2,038 & 1 \\
\hline
\end{tabular}

Keterangan: Perbandingan rasio tepung beras merah dan kacang hijau 40:60 untuk F1, 50:50 untuk F2 dan 60:40 untuk F3. *Formula terpilih

Formula terpilih merupakan formula dengan jumlah skor terbesar. Berdasarkan Tabel 1.3 formula dengan skor terbesar yaitu F3 dengan total skor 2,038, sehingga F3 menjadi formula terpilih dengan perbandingan rasio tepung beras merah dan kacang hijau 60g : $40 \mathrm{~g}$. Hasil dari kontribusi snack bar pertakaran saji dan kontribusi terhadap nilai AKG secara umum dapat dilihat pada Tabel 1.4.

Tabel 1.4 Kandungan zat gizi snack bar pertakaran saji dan persentase kontribusi zat gizi snack bar terhadap AKG dan ALG

\begin{tabular}{lccc}
\hline Komposisi & $\begin{array}{c}\text { Kandungan gizi snack } \\
\text { bar (50g) }\end{array}$ & $\begin{array}{c}\text { \% kontribusi } \\
\text { kandungan gizi snack } \\
\text { bar terhadap AKG }\end{array}$ & $\begin{array}{c}\text { \% kontribusi } \\
\text { kandungan gizi snack } \\
\text { bar terhadap ALG }\end{array}$ \\
\hline Energi (Kcal) & 198,3 & 18,4 & \\
Protein (g) & 4 & 13,3 & \\
Lemak (g) & 9,05 & 27 & 18 \\
Karbohidrat (g) & 25,2 & 15,5 & \\
Serat (g) & 1,08 & 3,6 & \\
\hline
\end{tabular}

keterangan : *Kontribusi tiap takaran saji terhadap AKG (Kemenkes, 2017) usia kelompok umum

**Kontribusi tiap takaran saji terhadap ALG (BPOM, 2016).

Tabel 1.4 menunjukan bahwa snack bar dengan berat $50 \mathrm{~g}$ sudah dapat memenuhi syarat makanan selingan yaitu mengandung energi sebesar $10-15 \%$ dari AKG dan dapat menyumbangkan serat sebesar $3,6 \%$ dalam 100 g produk snack bar.

\section{PEMBAHASAN}

Penggunaan tepung beras merah dan kacang hijau dalam produk snack bar bertujuan untuk meningkatkan kandungan serat pada produk tersebut. Namun pada penelitian ini kandungan serat snack bar rendah. Rendahnya kandungan serat pada snack bar dapat terjadi karena adanya proses pengolahan pada pembuatan snack bar [8]. Proses perendaman dapat menurunkan kadar serat pangan, karena larutnya komponen serat dalam perendaman air. Proses perebusan dan pemanasan kacang hijau juga menyebabkan penurunan kadar serat. Semakin lama proses perebusan dan pemanasan, semakin merusak kandungan serat dalam bahan pangan [9][10].

Penurunan kadar serat saat proses perendaman, perebusan dan pengeringan terjadi karena ketika pati mengalami pemanasan maka granula pati akan membengkak dan terjadi gelatinisasi sehingga ketika pemanasan, kadar pati meningkat. Kandungan pati berkolerasi dengan kandungan serat, ketika mengalami pemanasan yang terus menerus maka kandungan pati mengalami penurunan yang diikuti dengan penurunan serat pada bahan pangan. 
Kadar serat dapat dipengaruhi oleh proses penepungan [11]. Tepung beras merah yang digunakan pada penelitian ini yaitu tepung beras komersil. Proses pembuatan tepung beras komersil dilakukan dengan cara langkah pertama yaitu pemilihan jenis bahan, membersihkan bahan dasar, selanjutnya bahan dasar direndam dengan air bersih terkebih dahulu kemudian keringkan waktu yang dibutuhkan selama proses perendaman sekitar 12 jam dan langkah terakhir dilakukan pengeringan sempurna dengan kadar air kurang lebih 10\% dan kemudian dilakukan proses penggilingan dilanjutkan dengan pengayakan. [12] Selain itu, kadar serat juga dipengaruhi oleh variasi dari metode penepungan yang terbagi menjadi tiga yaitu metode penepungan kering, basah dan semi-kering. Hasil penelitian menyatakan bahwa kandungan serat pada tepung beras merah pada metode penepungan basah lebih kecil atau mengalami penurunan dan kandungan serat tepung beras merah pada metode penepungan kering lebih tinggi jika dibandingan dengan metode penepungan semi-kering dan basah [13] Hal ini karena dalam metode penepungan basah melalui proses pencucian dan perendaman yang dapat menurunkan kandungan serat pada tepung beras merah.

Uji hedonik dari parameter warna, aroma, rasa dan tektur dalam penelitian ini adalah untuk melihat tingkat kesukaan panelis terhadap parameter uji hedonik snack bar tepung beras merah dan kacang hijau. Berdasarkan analisis uji hedonik dari tiga formula snack bar tepung beras merah dan kacang hijau tidak ada pengaruh rasio tepung beras dan kacang hijau dari parameter uji hedonik. Hal ini dimungkinkan karena perbedaan range umur panelis tidak berbeda jauh yaitu ratarata panelis tergolong dalam usia dewasa 23-35 tahun. Jenis kelamin dan kondisi fisiologis panelis juga dapat mempengaruhi kepekaan meliputi kondisi lapar atau kenyang, kelelahan, sakit, obat bangun tidur dan merokok [14][15].

Warna yang dihasilkan dari tiap formula snack bar tepung beras merah dan kacang hijau tidak menunjukkan perbedaan, hal ini disebabkan karena formulasi tepung beras merah dan kacang hijau yang digunakan tidak berbeda jauh pada setiap perlakuannya dan penambahan coklat sebagai bahan tambahan tidak menghasilkan perbedaan warna yang signifikan sehingga panelis tidak dapat membedakan warna snack bar pada setiap formula [16]. Warna pada snack bar dapat berubah saat mengalami perlakuan dan proses pembuatan, seperti pemberian bahan tambahan dan proses pengolahannya [17]. Warna kecoklatan pada snack bar bisa terjadi karena adanya proses pencoklatan pada bahan (Browning non enzimatis) disebabkan oleh reaksi pencoklatan tanpa pengaruh enzim, biasanya terjadi saat pengolahan berlangsung seperti proses karamelisasi pada gula, pencokelatan yang disebabkan karena bertemunya gula reduksi dan asam amino pada suhu tinggi dan waktu lama [18]. Dalam penelitian ini, warna coklat yang dihasilkan snack bar ditimbulkan oleh penambahan coklat blok sebanyak $10 \mathrm{~g}$ di setiap formulasinya, juga dipengaruhi oleh proses karamelisasi dari madu. Reaksi maillard yang terjadi pada proses pemanggangan juga mengakibatkan warna coklat pada snack bar [19].

Aroma yang dihasilkan snack bar disebabkan karena adanya proses karamelisasi gula dan adanya proses pemanggangan membentuk aroma khas [20] Aroma yang dihasilkan oleh tiap formula snack bar adalah aroma margarin, aroma kacang hijau dan tepung beras merah. Aroma juga dipengaruhi proses pemanggangan, dimana tujuan pemanggangan yaitu untuk mendapatkan cita rasa yang menarik serta aroma yang khas [21][22].

Rasa dari snack bar tepung beras merah dan kacang hijau menghasilkan rasa manis yang didapatkan dari bahan tambahan yang digunakan seperti madu, gula dan susu skim [23]. namun begitu, dalam penelitian lain melaporkan bahwa jumlah tepung beras merah dan kacang hijau tidak berpengaruh terhadap rasa snack bar yang dihasilkan karena rasa manis didapatkan dari bahan tambahan lainnya dalam jumlah yang sama dari tiap formula [24]. Rasa manis yang terdapat 
pada food bar diperoleh dari penambahan gula selain itu penambahan margarine juga dapat digunakan sebagai pembangkit rasa food bar [25].

Tekstur snack bar pada umumnya bersifat lengket dan lembut [26]. Tekstur snack bar pada penelitian ini bersifat empuk. Hal ini dapat dipengaruhi oleh penggunaan madu [25]. Tekstur juga dipengaruhi oleh kandungan air yang akan membuat tekstur menjadi lunak, bahan yang digunakan, ketebalan cetakan dan suhu oven yang tinggi[27][28].

Snack bar F3 menjadi formula terpilih yang kemudian kandungan gizinya di dibadingkan dengan persentase AKG perorang perhari dan persentase ALG untuk klaim produk olahan. Produk snack bar tepung beras merah dan kacang hijau dapat dikategorikan sebagai makanan selingan tinggi energi dan sumber serat, namun tidak dapat diklaim sebagai makanan selingan tinggi serat. Hal ini dikarenakan berdasarkan ALG pangan harus mengandung serat sebanyak 6 gram atau $20 \%$ dalam $100 \mathrm{~g}$ produk untuk dapat diklaim sebagai makanan tinggi serat. Dalam penelitian ini produk snack bar dengan berat $50 \mathrm{~g}$ belum bisa memenuhi syarat klaim sumber serat karena hanya dapat menyumbangkan serat sebesar 2,16 g namun begitu formula terpilih dari snack bar tepung beras merah dan kacang hijau belum dapat memberi kontribusi asupan serat harian sesuai denganAKG.

\section{DAFTAR PUSTAKA}

1. Ariani, M. (2010). Analisis konsumsi pangan tingkat masyarakat mendukung pencapaian diversifikasi pangan. Gizi Pangan Indonesia.

2. Widyastuti, DA. (2018). Pengaruh Kebiasaan Konsumsi Junk Food Terhadap Kejadian Obesitas Remaja. https://doi.org/10.31219/osf.io/7d8 ey

3. Hartari, A. (2016). Pola Konsumsi Masyarakat Perkotaan dan Pengaruhnya Terhadap Kesehatan.

4. World Health Organization, (2017). Dialy dietary fiber intake

5. RI, Kemenkes, and Kementrian Kesehatan RI. "Peraturan Menteri atau $18 \%$ per 100 g produk. Namun begitu, snack bar ini dapat memenuhi syarat makanan selingan dengan mengonsumsi sebanyak 5 bungkus atau 250g pertakaran saji. Snack bar tepung beras merah dan kacang hijau memiliki energi yang lebih tinggi jika dibandingkan dengan snack bar komersil, namun untuk kandungan serat snack bar komersil lebih tinggi 1,92g dibanding snack bar tepung beras merah dan kacang hijau. Hal ini diduga karena snack bar komersil menggunakan bahan dasar dari tepung kedelai dan penambahan jenis kacang-kacangan lainnya yang merupakan sumber tinggi serat, sehingga kandungan seratnya lebih tinggi [29].

\section{SIMPULAN}

Kesimpulan dari penelitian ini adalah Perbedaan rasio tepung beras dan kacang hijau tidak berpengaruh terhadap kandungan serat pada snack bar. Perbedaan rasio tepung beras dan kacang hijau tidak berpengaruh terhadap uji hedonik dari parameter warna, aroma, rasa dan tekstur pada snack bar tepung beras merah dan kacang hijau. Snack bar F3 menjadi formula terbaik dengan rasio tepung beras merah dan kacang hijau 60:40,

Kesehatan Republik Indonesia Nomor 75 Tahun 2013 tentang angka kecukupan gizi yang dianjurkan bagi bangsa Indonesia." Jakarta: Kementerian Kesehatan RI (2013).

6. Ferawati, 2009. Formulasi dan Pembuatan Banana Bars berbahan Dasar Tepung Kedelai, Terigu, Singkong, dan Pisang sebagai Alternative Panga Darurat.

7. Amalia, R. 2011. Kajian Karakteristik Fisiok Kimia Dan Organoleptik Snack Bar dengan Bahan Dasar Tepung Tempe dan Buah Nangka Kering sebagai Alternative Pangan CFGF (Casein Free Gluten Free).

8. Pricilya, V., Wirjatmadi, B., \& Andriani, M. (2017). Daya Terima Proporsi Kacang Hijau (Phaseolus Radiata L) dan Bekatul (Rice Bran) Terhadap Kandungan Serat Pada Snack Bar. Media Gizi Indonesia, 10(2), 136-140. 
9. Lusiyatiningsih, T. (2014). Uji Kadar Serat, Protein Dan Sifat Organoleptik Pada Tempe Dari Bahan Dasar Kacang hijau (Phaseolus Radiatus L) Dengan Penambahan Bekatul Dan Tepung Jagung (Doctoral dissertation, Universitas Muhammadiyah Surakarta).

10. Diana, N. E. (2017). Pengaruh waktu perebusan terhadap kandungan proksimat, mineral dan kadar serat tepung biji kapas. Jurnal Penelitian Pascapanen Pertanian.

11. Astarini, F. (2013). Formulasi Dan Evaluasi Sifat Sensoris Dan Fisikokimia Flakes Komposit Dari Tepung Tapioka, Tepung Konjac (Amorphophallus Oncophyllus) Dan Tepung Kacang Hijau (Phaseolus Radiatus L)

12. Wahjuningsih, S. B., Septiani, A. R., \& Haslina, H. (2018). Organoleptik cereal dari tepung beras merah (Oryza nivara Linn.) dan tepung kacang merah (Phaseolus vulgaris Linn.). Jurnal Litbang Provinsi Jawa Tengah, 16(2), 131-142. leptik Produk Roti Manis di Kota Malang. Jurnal Pangan dan Agroindustri.

13. Annisa, I. (2015). Perbedaan Kualitas Egg Roll Berbahan Dasar Tepung Beras Merah Varietas Oryza Glaberrima dengan Penerapan Metode Penepungan yang Berbeda (Doctoral dissertation, Universitas Negeri Semarang).

14. Agusman. (2013). Pengujian organoleptik. Semarang: Program Studi Teknologi Pangan Unimus.

15. Maligan, J. M., Amana, B. M., \& Putri, W. D. R. (2019). Analisis Preferensi Konsumen Terhadap Karakteristik Organoptik.

16. Arwin et, al. (2018). Kajian Penilaian Organoleptik dan Nilai Gizi Snack Bar Berbasis Tepung Beras Merah dan Kacang Merah ( Phaseolus Vulgaris L.) sebagai Makanan Selingan yang Berserat Tinggi. Jurnal Sains dan Teknologi Pangan.

17. Wulandari, A., Ikawati, R., TP, S., Rakhma, L. R., Gz, S., \& Gizi, M. (2017). Pengaruh Proporsi Tepung Ubi Jalar
Ungu (Ipomoea Batatas L.) Dan Tepung Kacang Merah (Phaseolus Vulgaris L.) Pratanak Pada Pembuatan Food Bar Terhadap Daya Patah Dan Daya Terima (Doctoral dissertation, Universitas Muhammadiyah Surakarta).

18. Arsa, M. (2016). Proses Pencoklatan (Browning Process) Pada Bahan Pangan. Universitas Udayana Denpasar.

19. Dewi. P.D., Wijanarka. A., Febriana. N. (2016). Pengaruh Variasi Pencampuran Tepung Beras Merah (Oryza Nivara) Dan Tepung Terigu Terhadap Sifat Fisik, Organoleptik dan Kadar Antosianin Bolu Kukus.

20. Anggraeni, L dan Nurminabari, I. S. (2019). Kajian perbandingan tepung beras merah (oryza nivara) dengan tepung kacang kedelai (glycine max) dan konsentrasi gula terhadap karakteristik food bars (Doctoral dissertation, Fakultas Teknik Unpas).

21. Luthfiani Nur Pratiwi, L. N. P., Tjarono Sari, T. S., \& Noor Tifauzah, N. T. (2017). Analisa kadar protein dan kadar serat pada snack bars berbahan campuran tepung cassava dan tepung kacang merah (Doctoral dissertation, Poltekkes Kemenkes Yogyakarta).

22. Rahardjo, L. J., Bahar, A., \& Adi, A. C. (2019). Pengaruh kombinasi kacang kedelai (glycine max) dan kacang tunggak (vigna unguiculata (l) walp.) Yang diperkaya biji nangka (artocarpus heterophyllus) terhadap daya terima dan kadar protein snack bar. Amerta Nutrition, 3(1), 71-77.

23. Andriani, Wa Ode Risky Ayu. (2019). Karateristik Organoleptik Dan Nilai Gizi Snack Bar Berbasis Tepung Beras Merah (Oryza Nivara) Dan Tepung Jagung (Zea Mays L.) Sebagai Makanan Selingan Tinggi Serat. Jurnal Sains dan Teknologi Pangan 3.6

24. Rahman, Taufi k. (2011). Pemanfaatan Kacang Hijau (Phaseolus Radiata L) Menjadi Susu Kental Manis Kacang Hijau. Prosiding SnaPP2011 Sains, Teknologi dan Kesehatan. ISSN: 20893582.

25. Kusumastuty. I., Laily. F., dan Arliek. R. 
J., 2015. Formulasi Food Bar Tepung Bekatul dan Tepung Jagung sebagai Pangan Darurat. Indonesian Journal of Human Nutrition.

26. Beets, M. W., Tilley, F., TurnerMcGrievy, G., Weaver, R. G., \& Jones, S. (2014). Community partnership to address snack quality and cost in after-school programs. Journal of school health, 84(8), 543-548.

27. Avianty, S., \& Ayustaningwarno, F. (2016). Indeks glikemik snack bar ubi jalar kedelai hitam sebagai alternatif makanan selingan penderita diabetes melitus tipe 2 . Jurnal Aplikasi Teknologi Pangan, 3(3).

28. Rahmadhani, S., Theo, R. F., \& Nombiga, T. E. (2012). Uji Penerimaan (Uji Hedonik dan Uji Mutu Hedonk). Bogor: Institut Pertanian Bogor.

29. Rufaizah, Ummi. "Pemanfaatan Tepung Sorghum (Sorghum bicolor L moench) pada Pembuatan Snack Bar Tinggi Serat Pangan dan Sumber Zat Besi Untuk Remaja Puteri. IPB. Bogor (2011). 